\title{
ANALISIS KINERJA KEUANGAN PADA KOPERASI PEGAWAI NEGERI (KPN) PEMDA PROVINSI BENGKULU
}

\author{
Ovita Charolina ${ }^{1}$, Azuwandri ${ }^{2}$ \\ ${ }^{1,2}$ Sekolah Tinggi Ilmu Administrasi Bengkulu \\ Email : inacharol@gmail.com, azuwandri08@gmail.com
}

\begin{abstract}
ABSTRAK
Analisa rasio keuangan merupakan suatu angka yang menunjukkan hubungan antara unsur-unsur dalam laporan keuangan. Analisis rasio keuangan dapat menjelaskan atau memberi gambaran kepada penganalisis tentang baik buruknya keadaan atau posisi keuangan suatu perusahaan. Tujuan penelitian adalah untuk menganalisis kinerja keuangan pada Koperasi Pegawai Negeri (KPN) Pemda Provinsi Bengkulu. Hasil analisis likuiditas dilihat dari current ratio dan cash ratio. Current ratio tahun 2017 sebesar 5.434,93 \% dengan penilaian tidak sehat, tahun 2018 sebesar 3.655,88 \% dengan penilaian tidak sehat, tahun 2019 sebesar 2.748,35\% dengan penilaian tidak sehat. Cash ratio pada tahun 2017 sebesar 204,22 \% dengan penilaian sehat sekali, tahun 2018 sebesar 430,56 \% dengan penilaian tidak sehat, tahun 2019 sebesar 358,45\% dengan penilaian tidak sehat. Hasil analisis aspek tata laksana dan manajemen dari rasio realisasi anggaran pendapatan pada tahun 2018 sebesar $113.7 \%$ dengan penilaian sehat sekali, tahun 2017 sebesar $60.27 \%$ dan tahun 2019 sebesar 71,4 \% dengan penilaian cukup sehat. Hasil analisis rentabilitas dilihat dari rasio rentabilitas modal sendiri dan ratio return on asset (ROA). Rentabilitas modal sendiri pada tahun 2017 sebesar 18,90 \% dengan penilaian sehat, tahun 2018 sebesar 18,55 \% dengan penilaian sehat, tahun 2019 sebesar 18,13\% dengan penilaian sehat karena angka-angka tersebut berada diantara $15 \%$ - 21\%. Hal ini menggambarkan bahwa penilain terhadap rasio rentabilitas modal sendiri pada Koperasi Pegawai Negeri (KPN) Pemda Provinsi Bengkulu diketahui sehat, karena koperasi mampu mengelola modalnya dengan baik karena koperasi tidak mengalami rugi dan koperasi dapat mencapai keuntungan yang selalu meningkat dari tahun ketahun. Hasil ratio return on asset (ROA) tahun 2017 sebesar 11,17 \% dengan penilaian sehat sekali, tahun 2018 sebesar 15,13\% dengan penilaian sehat sekali, tahun 2019 sebesar 17,52\% dengan penilaian sehat sekali karena angka tersebut besar dari $10 \%$. Hal ini menggambarkan bahwa penilain rasio rentabilitas yang dinilai dari ratio return on asset sehat sekali, karena koperasi mampu mengeefektifkan perusahaannya dalam mengelola asset koperasi sehingga koperasi dapat meningkat.
\end{abstract}

\section{Kata Kunci : Likuiditas, Aspek Tata Laksana dan Manajemen, Rentabilitas}

\section{ABSTRACT}

The purpose of the study was to analyze the financial performance of the Civil Service Cooperative (KPN) of the Bengkulu Province Government. The results of the liquidity analysis can be seen from the current ratio and cash ratio. Current ratio in 2017 was 5,434.93\% with an unhealthy assessment, in 2018 it was 3,655.88\% with an unhealthy assessment, in 2019 it was 2,748.35\% with an unhealthy assessment. Cash ratio in 2017 was 204.22\% with a very healthy assessment, in 2018 it was $430.56 \%$ with an unhealthy assessment, in 2019 it was $358.45 \%$ with an unhealthy assessment. 
The results of the analysis of governance and management aspects of the revenue budget realization ratio in 2018 amounted to $113.7 \%$ with a very healthy assessment, in 2017 amounted to $60.27 \%$ and in 2019 amounted to $71.4 \%$ with a fairly healthy assessment. The results of the analysis of profitability can be seen from the ratio of own capital profitability and the ratio of return on assets (ROA). Own capital profitability in 2017 amounted to $18.90 \%$ with a healthy assessment, in 2018 amounted to $18.55 \%$ with a healthy assessment, in 2019 amounted to $18.13 \%$ with a healthy assessment because these figures are between $15 \%-21 \%$. The results of the return on asset (ROA) ratio in 2017 of $11.17 \%$ with a very healthy assessment, in 2018 of $15.13 \%$ with a very healthy assessment, in 2019 of $17.52 \%$ with a very healthy assessment because the figure is greater than $10 \%$.

Keywords: Liquidity, Aspects of Governance and Management, Rentability.

\section{PENDAHULUAN}

Sudah menjadi kodrat manusia diciptakan sebagai makhluk yang bergelut di bidang ekonomi, baik secara personal maupun kolektif, dalam memenuhi kebutuhan hidup, yang pada satu sisi tidak terbatas dan pada sisi lain dihadapkan pada sumber-sumber terbatas. Sebagai bagian aktivitas manusia, kegiatan ekonomi tak dapat dielakkan, guna memenuhi kebutuhan hidup itu dan dalam rangka menjalankan tanggung jawab manusia (Kartasapoetra, dkk, 2010:1). Di dalam perekonomian untuk mensejahterakan masyarakat ada yang dinamakan dengan perusahaan atau badan usaha yang bergerak di dalam perkumpulan orang-orang yang umumnya berekonomi lemah yang bergabung secara sukarela dan atas dasar persamaan hak, berkewajiban melakukan suatu usaha yang bertujuan untuk memenuhi kebutuhan-kebutuhan para anggotanya yang disebut dengan koperasi. Badan usaha koperasi ini sesuai dengan sifat bangsa Indonesia yang suka bekerjasama dengan bergotong-royong, namun dalam menjalankan kegiatan koperasi ini harus didukung dengan laporan keuangan (Rudianto, 2012:86).

Koperasi memerlukan pengukuran kinerja keuangan koperasi untuk mengukur keberhasilan koperasi dalam meningkatkan kesejahteraan anggota- nya. Pengukuran kinerja keuangan dapat dilakukan dengan menganalisis laporan keuangannya. Menganalisis laporan keuangan berarti menggali lebih banyak informasi yang terkandung dalam suatu laporan keuangan koperasi. Analisa rasio merupakan suatu angka yang menunjukkan hubungan antara unsur-unsur dalam laporan keuangan. Analisis rasio dapat menjelaskan atau memberi gambaran kepada penganalisis tentang baik buruknya keadaan atau posisi keuangan suatu perusahaan, terutama apabila angka tersebut dibandingkan dengan angka rasio pembanding yang digunakan sebagai standar. Ini sama halnya untuk koperasi, apabila angka rasio tersebut dibandingkan dengan standar penilaian kinerja koperasi maka dapat diketahui kondisi dari koperasi tersebut. Analisis rasio tersebut dapat digunakan untuk mengetahui kinerja keuangan dari koperasi tersebut, khususnya mengenai likuiditas, aktivitas, dan profitabilitas dari koperasi tersebut (Afriyanti, 2011:10).

Koperasi Pegawai Negeri (KPN) Pemda Provinsi Bengkulu merupakan koperasi yang dimiliki oleh Pegawai Negeri Pemda Provinsi Bengkulu yang usahanya bergerak dalam simpan pinjam dari semua anggota koperasi. Dengan adanya koperasi tersebut dapat mensejahterahkan para anggota koperasi, membangun aktifitas ekonomi bersama, berpijak pada kekuatan sendiri dan 
kesamaan derajat dalam rangka mencapai perbaikan kehidupan ekonomi. Menurut Tempo CO. Bengkulu (2018) bahwa Pegawai Negeri Sipil Pemerintah Provinsi Bengkulu memiliki kebiasaan menunggak utang. Hal tersebut diketahui dalam rapat tahunan (RAT). Tunggakan utang anggota Koperasi Pegawai Negeri (KPN) Pemerintah Provinsi Bengkulu diketahui mencapai Rp 50 juta. Tunggakan utang ini biasanya terjadi karena para PNS, jika pindah tugas dinas, pensiun, dan sebagainya, ikut meninggalkan utangnya di koperasi. Dari uraian di atas latar belakang sehingga penulis merasa perlu untuk melakukan sebuah penelitian dengan memilih judul "Analisis Kinerja Keuangan Pada Koperasi Pegawai Negeri (KPN) Pemda Provinsi Bengkulu.

\section{TINJAUAN LITERATUR \\ Koperasi}

Koperasi berasal dari bahasa Inggris cooperation yang berarti usaha bersama. Dengan arti lain adalah segala bentuk pekerjaan yang dilakukan secara bersama-sama sebenarnya dapat dikatakan sebagai koperasi. Tetapi yang dimaksud koperasi dalam hal ini bukanlah segala bentuk pekerjaan yang dilakukan secara bersama-sama dalam arti yang sangat umum tersebut. Secara umum yang dimaksud dengan koperasi adalah suatu badan usaha bersama yang bergerak di bidang perekonomian, beranggotakan mereka yang umumnya berekonomi lemah yang bergabung secara sukarela dan atas dasar persamaan hak, berkewajiban melakukan suatu usaha yang bertujuan untuk memenuhi kebutuhan-kebutuhan para anggotanya (Kartasapoetra, dkk, 2010:1).

Modal Sendiri menurut Undang-Undang No. 25 tahun 1992 adalah modal yang menangung risiko atau disebut modal ekuiti. Apabila dalam suatu tahun buku, Koperasi menderita kerugian maka yang harus menanggung kerugian tersebut adalah komponen Modal Sendiri. Modal Sendiri menurut UU No.25 tahun 1992 pasal 41, sebagai berikut:

a. Simpanan Pokok

b. Simpanan Wajib

c. Dana Cadangan

d. Hibah

e. Sisa Hasil Usaha Koperasi merupakan pendapatan Koperasi yang diperoleh dalam satu tahun buku dikurangi dengan biaya, penyusutan, dan kewajiban lainnya termasuk pajak dalam tahun buku yang bersangkutan.

f. Sisa Hasil Usaha setelah dikurangi dana cadangan, dibagikan kepada anggota sebanding dengan jasa usaha yang dilakukan oleh masingmasing anggota dengan Koperasi, serta digunakan untuk keperluan pendidikan perkoperasian dan keperluan lain dari Koperasi, sesuai dengan keputusan Rapat Anggota.

\section{Koperasi Pegawai Negeri Sipil}

Menurut Hadi (2011:63) mengemukakan bahwa koperasi pegawai negeri adalah koperasi fungsional yang anggotanya berpenghasilan tetap. Dengan adanya penghasilan tetap para anggotanya, maka koperasi tersebut dapat memobilisasi dana dengan menggerakkan simpanan anggota secara teratur. Lebih lanjut Sumitro (2010:82) mengemukakan bahwa koperasi pegawai negeri adalah koperasi golongan konsumen. Namun demikian, dalam perkembangannya sudah tentu koperasi konsumen bertujuan untuk memelihara kepentingan dan memenuhi kebutuhan para anggotanya (keluarga pegawai negeri sebagai konsumen) dengan menjalankan kegiatan usaha di 
bidang niaga maupun di bidang produksi dan sebagainya. Apalagi jika mengingat bahwa kesejahteraan pegawai negeri menyangkut serangkaian kebutuhan yang paling dirasakan dewasa ini, yaitu pangan, sandang, pemukiman, pendidikan dan kesehatan. Dalam pandangan Sumitro (2010:84) bahwa perjuangan dan aktivitas koperasi pegawai negeri hendaknya diarahkan ketujuan :

1. Minimal mempertahankan tingkat hidup anggota-anggotanya sebagai landasan dan pangkal tolak untuk meningkatkan kesejahteraan hidupnya.

2. Maksimal memperbaiki kesejahteraan anggota-anggotanya dengan jalan menjalankan aktivitas usaha koperasi sebaik-baiknya sehingga dapat menghasilkan sisa hasil usaha yang optimal

\section{Laporan Keuangan Koperasi}

Menurut Sutrisno (2012:9) mengemukakan bahwa laporan keuangan merupakan hasil akhir dari proses akuntansi yang meliputi dua laporan utama yakni Neraca dan laporan Laba Rugi .Kasmir (2011:7) berpendapat bahwa laporan keuangan adalah laporan yang menunjukkan kondisi keuangan perusahaan pada saat ini atau dalam suatu periode tertentu. Berdasarkan beberapa uraian di atas, maka dapat ditarik kesimpulan bahwa laporan keuangan adalah suatu laporan yang menggambarkan posisi keuangan perusahaan pada suatu periode tertentu sesuai dengan prinsip-prinsip akuntansi yang dilaksanakan secara konsisten serta dibuat dan disajikan dalam bentuk neraca dan laporan laba rugi.

Dari pendapat ahli ekonomi di atas, maka dapat disimpulkan bahwa laporan keuangan merupakan hasil akhir proses akuntansi yang menjelaskan atau melaporkan kegiatan perusahaan sekaligus untuk mengevaluasi keberhasilan strategi perusahaan dalam pencapaian tujuan yang ingin dicapai. Setelah laporan keuangan perusahaan dilaksanakan, maka diadakan rapat anggota tahunan yang biasa disebut Rapat Anggota Biasa. Rapat Anggota Biasa adalah rapat anggota yang diselenggarakan oleh koperasi yang sifatnya rutin sekali dalam satu tahun. Pelaksanaan Rapat Anggota Tahunan harus dilaksanakan tepat pada waktunya sesuai Petunjuk Pelaksanaan UndangUndang No 25 Tahun 1992 Pasal 2, "Rapat Anggota untuk mengesahkan pertanggungjawaban pengurus diselenggarakan paling lambat 6 (enam) bulan setelah tahun buku lampau”. Demi menjaga sifat kerahasiaan dari urusan intern koperasi tanpa mengurangi sifat terbukanya kepada para anggota-anggota koperasi sendiri, acara RAT diatur sebagai berikut :

1) Bagian umum yang bersifat terbuka selain untuk anggota, pejabat,pengurus dan juga bisa dihadiri oleh para undangan lainnya yang acara pokoknya berisi sambutan-sambutan umum, amanat (jika ada) tanpa secara langsung membicarakan masalah-masalah intern Koperasi atau kebijaksanaan pengurus dan pengawas.

2) Bagian internal koperasi (bagian intern), setelah acara umum diselesaikan dilanjutkan istirahat sambil memberikan kesempatan bagi para undangan meninggalkan ruangan rapat. Selanjutnya rapat merupakan rapat intern koperasi yang merupakan Rapat Anggota Tahunan yang sebenarnya membahas pertanggung jawaban Pengurus, laporan pengawas, serta evaluasi/penilaian pejabat serta kinerja atau rencana usaha yang dijalankan oleh Koperasi.

\section{Analisa Laporan Keuangan}

Menurut Prastowo (2015: 50), Analisa laporan keuangan merupakan suatu proses yang penuh pertimbangan dalam rangka membantu evaluasi posisi keuangan dan hasil operasi perusahaan pada masa sekarang dan masa lalu, dengan tujuan utama untuk menentukan estimasi dan prediksi yang paling mungkin mengenai kondisi keuangan dan kinerja perusahaan pada masa mendatang. 
Menurut Harahap (2009 : 195), kegunaan analisis laporan keuangan ini dapat dikemukakan sebagai berikut:

1. Dapat memberikan informasi yang lebih luas, lebih dalam dari pada yang terdapat dari laporan keuangan biasa.

2. Dapat menggali informasi yang tidak tampak secara kasat mata (explicit) dari suatu laporan keuangan atau yang berada di balik laporan keuangan (implicit).

3. Dapat mengetahui kesalahan yang terkandung dalam laporan keuangan.

4. Dapat membongkar hal - hal yang bersifat tidak konsisten dalam hubungannya dengan suatu laporan keuangan baik dikaitkan dengan komponen intern maupun kaitannya dengan informasi yang diperoleh dari luar perusahaan.

5. Mengetahui sifat-sifat hubungan yang akhirnya dapat melahirkan model-model dan teori-teori yang terdapat di lapangan seperti untuk prediksi, peningkatan.

6. Dapat memberikan informasi yang diinginkan oleh para pengambil keputusan

7. Dapat menentukan peringkat perusahaan menurut kriteria tertentu yang sudah dikenal dalam dunia bisnis.

Sedangkan Menurut Munawir (2010:31), tujuan analisis laporan keuangan merupakan alat yang sangat penting untuk memperoleh informasi sehubungan dengan posisi keuangan dan hasilhasil yang telah dicapai perusahaan yang bersangkutan. Menurut Harahap (2009:203), kelemahan analisis laporan keuangan adalah:

1. Analisis laporan keuangan didasarkan pada laporan keuangan, oleh karenanya kelemahan laporan keuangan harus selalu diingat agar kesimpulan dari analisis itu tidak salah.

2. Objek analisis laporan keuangan hanya laporan keuangan. Untuk menilai suatu laporan keuangan tidak cukup hanya angka-angka laporan keuangan.

3. Objek analisis adalah data historis yang menggambarkan masa lalu dan kondisi ini bisa berbeda dengan kondisi masa depan.

\section{Rasio Likuiditas}

Menurut Kasmir (2011:129) rasio likuiditas adalah rasio yang menggambarkan kemampuan perusahaan dalam memenuhi kewajiban (utang) jangka pendek. Artinya apabila perusahaan ditagih, perusahaan akan mampu utnuk memenuhi utang tersebut terutama utang yang sudah jatuh tempo. Rasio ini sering disebut sebagai rasio modal kerja. Tidak hanya Bank dan para kreditor jangka pendek saja yang tertarik dengan angka-angka rasio likuiditas, rasio likuiditas juga berguna bagi kreditor jangka panjang dan pemegang saham yang akhirnya atau setidaknya ingin mengetahui prospek dari deviden dan pembayaran bunga di masa yang akan datang (Munawir, 2010:77).

Adapun alat analisis yang digunakan untuk mengetahui tingkat likuiditas yaitu:

\section{a. Current Ratio}

Rasio lancar merupakan rasio untuk mengukur kemampuan perusahaan dalam membayar kewajiban jangka pendeknya.

$$
\text { Current Ratio }=\frac{\text { Aktiva Lancar }}{\text { Hutang Lancar }} \times 100 \%
$$

Adapun penilaian kinerja keuangan koperasi jika dilihat dari current ratio berdasarkan Peraturan Menteri Koperasi dan UKM Nomor: 06/Per/M. KUKM/V/2006 adalah : 
Tabel 1. Penilaian kinerja keuangan koperasi jika dilihat dari current ratio.

\begin{tabular}{|l|c|l|}
\hline \multicolumn{1}{|c|}{ Standar Penilaian } & Nilai & \multicolumn{1}{c|}{ Kriteria } \\
\hline $200 \%$ s/d $250 \%$ & 100 & Sehat Sekali \\
$175 \%-<200 \%$ atau $250 \%-275 \%$ & 75 & Sehat \\
$150 \%-<175 \%$ atau $>275 \%-300 \%$ & 50 & Cukup Sehat \\
$125 \%$ s/d $<150 \%$ atau $300 \%-325 \%$ & 25 & Kurang Sehat \\
$<125 \%$ atau $>325 \%$ & 0 & Tidak Sehat \\
\hline
\end{tabular}

\section{b. Acid Cash ratio}

Merupakan alat yang digunakan untuk mengukur seberapa besar uang kas yang tersedia untuk membayar utang.

$$
\text { Acid Cash Ratio }=\frac{\text { Kas }}{\text { HutangLancar }} \times 100 \%
$$

Adapun penilaian kinerja keuangan koperasi jika dilihat dari acid cash ratio berdasarkan Peraturan Menteri Koperasi dan UKM Nomor: 06/Per/M. KUKM/V/2006 adalah :

Tabel 2. Penilaian kinerja keuangan koperasi jika dilihat dari acid cash ratio

\begin{tabular}{|l|c|l|}
\hline \multicolumn{1}{|c|}{ Standar Penilaian } & Nilai & \multicolumn{1}{|c|}{ Kriteria } \\
\hline $200 \%$ s/d $250 \%$ & 100 & Sehat Sekali \\
$175 \%-<200 \%$ atau $250 \%-275 \%$ & 75 & Seha \\
$150 \%-<175 \%$ atau $>275 \%-300 \%$ & 50 & Cukup Sehat \\
$125 \%$ s/d $<150 \%$ atau 300\%-325\% & 25 & Kurang Seha \\
$<125 \%$ atau $>325 \%$ & 0 & Tidak Sehat \\
\hline
\end{tabular}

\section{Rasio Rentabilitas}

Menurut Riyanto (2010:28) rentabilitas adalah kemampuan suatu perusahaan untuk menghasilkan laba selama periode tertentu dan umumnya dirumuskan sebagai L/M, dimana L adalah jumlah laba yang diperoleh dalam periode tertentu dan $\mathrm{M}$ adalah modal atau aktiva yang digunakan untuk menghasilkan laba tersebut. Sedangkan menurut Kasmir (2011:196) rasio rentabilitas adalah rasio untuk menilai kemampuan perusahaan dalam mencari keuntungan. Rasio ini juga memberikan ukran tingkat efektivitas manajemn suatu perusahaan. Hal ini ditunjukkan oleh laba yang dihasilkan dari penjualan dan pendapatan investasi. Intinya adalah penggunaan rasio ini menunjukkan efisiensi perusahaan. Jenis rasio rentabilitas (profitabilatas) yang dapat digunakan adalah sebagai berikut : Berdasarkan Peraturan Menteri Koperasi dan UKM Nomor: 06/Per/M. KUKM/V/2006, adapun alat rentabilitas yang adalah:

a. Rentabilitas modal sendiri yaitu perbandingan antara hasil usaha yang diperoleh dengan asset koperasi pada tahun yang bersangkutan. Adapun rumus untuk menghitung rentabilitas modal sendiri menurut Peraturan Menteri Koperasi dan UKM Nomor: 06/Per/M. KUKM/V/2006 yaitu :

$$
\begin{aligned}
& \text { Rentabilitas Modal Sendiri } \\
& \qquad=\frac{\text { Sisa Hasil Usaha }}{\text { Modal Sendiri }} \times 100 \%
\end{aligned}
$$


Adapun penilaian kinerja keuangan koperasi jika dilihat dari rentabilitas ekonomi berdasarkan Peraturan Menteri Koperasi dan UKM Nomor: 06/Per/M. KUKM/V/2006 adalah :

Tabel 3. Penilaian kinerja keuangan koperasi jika dilihat dari rentabilitas ekonomi

\begin{tabular}{|l|c|l|}
\hline \multicolumn{1}{|c|}{ Standar Penilaian } & Nilai & \multicolumn{1}{|c|}{ Kriteria } \\
\hline$\geq 21 \%$ & 100 & Sehat Sekali \\
$15 \% \mathrm{~s} / \mathrm{d}<21 \%$ & 75 & Sehat \\
$9 \% \mathrm{~s} / \mathrm{d}<15 \%$ & 50 & Cukup Sehat \\
$3 \% \mathrm{~s} / \mathrm{d}<9 \%$ & 25 & Kurang Sehat \\
$<3 \%$ & 0 & Tidak Sehat \\
\hline
\end{tabular}

b. Return On Asset (ROA) merupakan perbandingan antara hasil usaha yang diperoleh dengan asset koperasi pada tahun yang bersangkutan. Adapun rumus untuk menghitung rentabilitas modal sendiri menurut Peraturan Menteri Koperasi dan UKM Nomor: 06/Per/M. KUKM/V/2006 yaitu :

$$
\begin{aligned}
& \text { Return On Asset (ROA) } \\
& =\frac{\text { Sisa Hasil Usaha }}{\text { Asset }} \times 100 \%
\end{aligned}
$$

Adapun penilaian kinerja keuangan koperasi jika dilihat dari rentabilitas modal sendiri berdasarkan Peraturan Menteri Koperasi dan UKM Nomor: 06/Per/M. KUKM/V/2006 adalah

Tabel 4. Penilaian kinerja keuangan koperasi jika dilihat dari rentabilitas modal sendiri

\begin{tabular}{|l|c|l|}
\hline \multicolumn{1}{|c|}{ Standar Penilaian } & Nilai & \multicolumn{1}{|c|}{ Kriteria } \\
\hline$\geq 10 \%$ & 100 & Sehat Sekali \\
$7 \% \mathrm{~s} / \mathrm{d}<10 \%$ & 75 & Sehat \\
$3 \% \mathrm{~s} / \mathrm{d}<7 \%$ & 50 & Cukup Sehat \\
$1 \% \mathrm{~s} / \mathrm{d}<3 \%$ & 25 & Kurang Sehat \\
$<1 \%$ & 0 & Tidak Sehat \\
\hline
\end{tabular}

\section{Kerangka Pemikiran}

Berdasarkan latar belakang rumus permasalahan serta kajian pustaka, maka dapat dibuat suatu kerangka analisis berikut ini:

\begin{tabular}{|c|c|c|}
\hline \multirow{3}{*}{$\begin{array}{l}\text { Laporan } \\
\text { Keuangan: } \\
\text { 1. Neraca } \\
\text { 2. PHU } \\
\text { (Perhitungan } \\
\text { Hasil Usaha) }\end{array}$} & \multirow{3}{*}{$\begin{array}{l}\text { 1. Rasio } \\
\text { Likuiditas } \\
\text { 2. Tata } \\
\text { laksanan } \\
\text { dan } \\
\text { manajemen } \\
\text { 3. Rasio } \\
\text { Rentabilitas }\end{array}$} & Kinerja Keuangan : \\
\hline & & $\begin{array}{l}\text { 1. Sehat Sekali } \\
\text { 2. Sehat } \\
\text { 3. Cukup Sehat } \\
\text { 4. Kurang Sehat } \\
\text { 5. } \\
\text { Tidak Sehat }\end{array}$ \\
\hline & & \\
\hline
\end{tabular}

\section{Gambar 1. Kerangka Analisis}


Dari kerangka analisis di atas dapat dijelaskan bahwa dari laporan keuangan neraca dan PHU pada Koperasi Pegawai Negeri (KPN) Pemda Provinsi Bengkulu tahun 2017 - 2019 dapat dihitung dan dilakukan analisis likuiditas dan rentabilitas terhadap kinerja keuangan Koperasi Pegawai Negeri Pemerintah Daerah Provinsi Bengkulu sehingga diketahui kinerja keuangannya sehat sekali, sehat, cukup sehat, kurang sehat, tidak sehat.

\section{METODE PENELITIAN \\ Jenis Penelitian}

Penelitian ini termasuk jenis penelitian kuantitatif, menurut Sugiyono (2013:15) metode kualitatif adalah penelitian yang berhubungan dengan ide, persepsi, pendapat, kepercayaan orang yang akan diteliti. Dalam penelitian ini akan menjelaskan mengenai kinerja keuangan yang terdiri dari rasio likuiditas dan rasio rentabilitas pada Koperasi Pegawai Negeri (KPN) Pemda Provinsi Bengkulu.

\section{Definisi Operasional}

a. Rasio likuiditas, adalah rasio yang menunjukkan kemampuan Koperasi Pegawai Negeri (KPN) Pemda Provinsi Bengkulu dalam memenuhi kewajiban lancarnya dengan aktiva lancar yang ada pada tahun 2017-2019.

b. Rasio Tata laksana dan manajemen ini dapat mengetahui bagaimana besarnya realisasi anggaran pendapatan dengan rencana pendapatan pada Koperasi Pemda Provinsi Bengkulu

c. Rasio rentabilitas, adalah rasio yang menunjukkan kemampuan Koperasi Pegawai Negeri (KPN) Pemda Provinsi Bengkulu untuk memperoleh PHU pada tahun 2017-2019.

\section{Metode Pengumpulan Data}

Metode pengumpulan data yang digunakan dalam penelitian ini adalah metode dokumentasi. Menurut Sugiyono (2013:326) dokumentasi merupakan catatan peristiwa yang sudah berlalu, dokumen bisa berbentuk tulisan dan gambar. Pada penelitian ini teknik dokumentasi akan diambil dengan cara mengumpulkan data-data yang dibutuhkan untuk penelitian seperti laporan keuangan Koperasi Pegawai Negeri (KPN) Pemda Provinsi Bengkulu yang terdiri dari laporan PHU dan laporan Rugi laba pada tahun 2017 sampai 2019.

\section{Metode Analisis}

Metode analisis data dalam penelitian ini menggunakan metode kuantitatif dengan menggunakan analisis rasio likuiditas dan rentabiltias berdasarkan Peraturan Menteri Koperasi dan UKM Nomor: 06/Per/M. KUKM/V/2006 sebagai berikut :

a. Rasio likuiditas

1. Current Ratio

$$
\text { CurrentRatio }=\frac{\text { Aktiva Lancar }}{\text { Hutang Lancar }} \times 100 \%
$$

2. Cash ratio

$$
\text { Cash Ratio }=\frac{\text { Kas }}{\text { Hutang Lancar }} \times 100 \%
$$


b. Aspek Tata Laksana dan Manajemen

Realisasi Anggaran Pendapatan Koperasi $=\frac{\text { Realisasi }}{\text { Rencana }}$ X 100\%

C. Rasio rentabilitas

1. Rentabilitas modal sendiri

Rentabilitas Modal Sendiri $=\frac{\text { Sisa Hasil Usaha }}{\text { Modal Sendiri }} \times 100 \%$

2. Return On Asset (ROA)

$$
\text { ROA }=\frac{\text { Sisa Hasil Usaha }}{\text { Asset }} \times 100 \%
$$

Untuk menentukan bahwa kinerja keuangan koperasi tersebut sehat atau tidak, maka digunakan standar pengukuran rasio seperti pada tabel 1 .

Tabel 1

Standar Pengukuran Rasio

\begin{tabular}{|c|c|c|c|}
\hline Jenis Rasio & Standar & Nilai & Kriteria \\
\hline \multirow{7}{*}{$\begin{array}{l}\text { Rasio } \\
\text { Likuiditas } \\
\text { a. Curent } \\
\text { Ratio }\end{array}$} & $200 \%$ s/d 250\% & 100 & Sehat Sekali \\
\hline & $\begin{array}{l}175 \% \text { s/d }<200 \% \text { atau } \\
250 \%-275 \%\end{array}$ & 75 & Sehat \\
\hline & $\begin{array}{l}150 \% \mathrm{~s} / \mathrm{d}<175 \% \text { atau } \\
275 \%-300 \%\end{array}$ & 50 & Cukup Sehat \\
\hline & $\begin{array}{l}125 \% \mathrm{~s} / \mathrm{d}<150 \% \text { atau } \\
300 \%-325 \%\end{array}$ & 25 & Kurang Sehat \\
\hline & $<125 \%$ atau $>325 \%$ & 0 & Tidak Sehat \\
\hline & $200 \%$ s/d $250 \%$ & 100 & Sehat Sekali \\
\hline & $\begin{array}{l}175 \% \text { s/d }<200 \% \text { atau } \\
250 \%-275 \%\end{array}$ & 75 & Sehat \\
\hline \multirow{3}{*}{$\begin{array}{l}\text { b. Cash } \\
\text { Ratio }\end{array}$} & $\begin{array}{l}150 \% \mathrm{~s} / \mathrm{d}<175 \% \text { atau } \\
275 \%-300 \%\end{array}$ & 50 & Cukup Sehat \\
\hline & $\begin{array}{l}125 \% \text { s/d }<150 \% \text { atau } \\
300 \%-325 \%\end{array}$ & 25 & Kurang Sehat \\
\hline & $<125 \%$ atau $>325 \%$ & 0 & Tidak Sehat \\
\hline \multirow{5}{*}{$\begin{array}{l}\text { Return On } \\
\text { Asset (ROA) }\end{array}$} & $\geq 10 \%$ & 100 & Sehat Sekali \\
\hline & $7 \% \mathrm{~s} / \mathrm{d}<10 \%$ & 75 & Sehat \\
\hline & $3 \% \mathrm{~s} / \mathrm{d}<7 \%$ & 50 & Cukup Sehat \\
\hline & $1 \% \mathrm{~s} / \mathrm{d}<3 \%$ & 25 & Kurang Sehat \\
\hline & $<1 \%$ & 0 & Tidak Sehat \\
\hline
\end{tabular}

Sumber: Peraturan Menteri Koperasi dan UKM Nomor: 06/Per/M. KUKM/V/2006 


\section{HASIL DAN PEMBAHASAN}

\section{Hasil Penelitian}

\section{Sejarah Berdirinya Koperasi Pegawai Negeri (KPN) Pemda Provinsi Bengkulu}

Berawal dari realitas minimnya gaji pegawai pada saat itu, membuat sebagian besar pegawai negeri Pemda Provinsi Bengkulu kesulitan memenuhi kebutuhan sehari-hari. Ketika melakukan pinjaman di luar suku bunga sangatlah tinggi hingga membuat kesulitan dalam pembayaran. Melihat keadaan itu maka muncul pemikiran untuk membuat koperasi dimana dengan koperasi bisa meringankan beban yang ada, selain peminjaman mudah dengan suku bunga realatif rendah, hasil laba yang terkumpul pun dapat dibagi keanggota.

Koperasi Pegawai Negeri (KPN) Pemda Provinsi Bengkulu didirikan berdasarkan Rapat Anggota pendirian Koperasi, dengan melihat latar belakang pendidikan maka dipilih pengurus koperasi yang akan menempati jabatannya masing-masing. Awal berdirinya Koperasi pegawai negeri ini berbentuk koperasi primer, dimana untuk memenuhi kebutuhan sehari-hari dikalangan Pegawai Negeri (KPN) Pemda Provinsi Bengkulu.

\section{Aktivitas Usaha Koperasi}

Koperasi merupakan perkumpulan orang-orang yang mempunyai kepentingan yang sama, bukan merupakan perkumpulan modal, batasan ini sering menimbulkan pendapat yang sempit pada sementara orang, bahwa kedudukan modal dalam koperasi tidaklah penting. Orang yang berpendapat demikian jelas memandang koperasi dengan bertitik berat pada fungsi koperasi sebagai alat sosial tanpa mengingat koperasi sebagai alat ekonomi. Anggota dalam koperasi Koperasi Pegawai Negeri (KPN) Pemda Provinsi Bengkulu adalah sebagai sumber permodalan sendiri dan sebagai peminjam. Oleh sebab itu kedudukan anggota sangat penting karena berada dalam semua subsistem keuangan mulai dari subsistem input, proses dan subsistem output.

Adapun aktivitas yang dilakukan oleh Koperasi Pegawai Negeri (KPN) Pemda Provinsi Bengkulu adalah :

1. Menghimpun dana dari setiap anggota Koperasi Pegawai Negeri (KPN) Pemda Provinsi Bengkulu seperti simpanan pokok, simpanan wajib dan simpanan sukarela

2. Menyalurkan dana yang telah terkumpul kepada anggota Koperasi Pegawai Negeri (KPN) Pemda Provinsi Bengkulu yang membutuhkan dengan ketentuan yang berlaku.

3. Membuat laporan keuangan Koperasi Pegawai Negeri (KPN) Pemda Provinsi Bengkulu yang akan dibicarakan pada Rapat Tahunan Koperasi Pegawai Negeri (KPN) Pemda Provinsi Bengkulu.

4. Membagikan sisa hasil usaha kepada semua anggota Koperasi Pegawai Negeri (KPN) Pemda Provinsi Bengkulu sesuai dengan ketentuan yang telah disepakati.

\section{Analisis Rasio}

a. Rasio likuiditas

Ratio Realisasi Anggaran Pendapatan adalah rasio yang menggambarkan kemampuan koperasi dalam memenuhi kewajiban (utang) jangka pendek. Ratio likuiditas terdiri dari :

1. Current Ratio

$$
\text { CurrentRatio }=\frac{\text { Aktiva Lancar }}{\text { Hutang Lancar }} \times 100 \%
$$


Berdasarkan laporan keuangan Koperasi Pegawai Negeri (KPN) Pemda Provinsi Bengkulu seperti pada lampiran 1 dan 3, maka dapat diketahui struktur aktiva lancar dan hutang lancar pada Koperasi Pegawai Negeri (KPN) Pemda Provinsi Bengkulu untuk tahun 2017 sampai 2019 seperti terlihat pada tabel 2 berikut ini:

Tabel 2

Data Aktiva Lancar, Hutang Lancar tahun 2017 sampai 2019 (Dalam Rupiah)

\begin{tabular}{|c|c|c|}
\hline Tahun & Aktiva Lancar & Hutang Lancar \\
\hline 2017 & 4.376 .758 .898 & 80.530 .174 \\
\hline 2018 & 3.872 .851 .635 & 105.934 .830 \\
\hline 2019 & 3.754 .964 .939 & 136.626 .124 \\
Sumber : Data diolah tahun 2020 \\
\hline
\end{tabular}

Berdasarkan tabel 2 di atas tentang struktur aktiva lancar dan hutang lancar selama tahun 2017, 2018 dan 2019 maka dapat dihitung besarnya current ratio sebagai berikut :

$$
\begin{aligned}
& \text { Curent Ratio } 2017=\frac{4.376 .758 .898}{80.530 .174} \times 100 \% \\
& =5.434,93 \% \\
& \text { Curent Ratio } 2018=\frac{3.872 .851 .635}{105.934 .830} \times 100 \%
\end{aligned}
$$$$
=3.655,88 \%
$$

Curent Ratio $2019=\frac{3.754 .964 .939}{136.626 .124} \times 100 \%$

$$
=2.748,35 \%
$$

Dari hasil perhitungan tersebut maka besarnya current ratio untuk tahun 2017 sampai dengan 2019 dapat dilihat pada tabel berikut ini :

Tabel 3

Hasil Perhitungan Current Ratio periode 2017-2019

\begin{tabular}{|c|c|l|c|}
\hline Tahun & Ratio & \multicolumn{1}{|c|}{ Standar } & Keterangan \\
\hline 2017 & $5.434,93$ & $\begin{array}{l}<125 \% \text { atau } \\
>325 \%\end{array}$ & Tidak Sehat \\
\hline 2018 & $3.655,88$ & $\begin{array}{l}<125 \% \text { atau } \\
>325 \%\end{array}$ & Tidak Sehat \\
\hline 2019 & $2.748,35$ & $\begin{array}{l}<125 \% \text { atau } \\
>325 \%\end{array}$ & Tidak Sehat \\
Sumber: Hasil Pengolahan Data, 2020 & \multicolumn{2}{l|}{} \\
\hline
\end{tabular}

Berdasarkan hasil perhitungan untuk current ratio pada Koperasi Pegawai Negeri (KPN) Pemda Provinsi Bengkulu dari tahun 2017 sampai dengan tahun 2019 dapat dilihat bahwa kemampuan Koperasi Pegawai Negeri (KPN) Pemda Provinsi Bengkulu dalam melunasi hutang 
jangka pendeknya pada tahun 2017 sebesar 5.434,93\% dengan penilaian tidak sehat, sedangkan tahun 2018 sebesar 3.655,88 \% dengan penilaian tidak sehat, tahun 2019 sebesar 2.748,35\% dengan penilaian tidak sehat. Hal ini mengambarkan bahwa aktiva lancar Koperasi Pegawai Negeri (KPN) Pemda Provinsi Bengkulu dapat menutupi semua hutang lancarnya. Namun meskipun harta yang dimiliki mampu membayar semua hutang lancar tetapi penilaian current ratio pada kategori tidak sehat, hal ini disebabkan karena banyaknya aktiva yang dimiliki koperasi tetapi koperasi belum mampu memanfaatkan aktiva tersebut secara maksimal, sehingga terjadilah penumpukan harga pada aktiva

2. Cash Ratio

Cash ratio merupakan rasio yang digunakan untuk mengukur seberapa besar uang kas yang tersedia untuk membayar utang Sehingga cash ratio dapat dihitung dengan menggunakan rumus

Cash Ratio $=\frac{\text { Kas }}{\text { Hutang Lancar }} \times 100 \%$

Berdasarkan laporan keuangan Koperasi Pegawai Negeri (KPN) Pemda Provinsi Bengkulu seperti pada lampiran 1 dan 3, maka struktur kas dan hutang lancar pada Koperasi Pegawai Negeri (KPN) Pemda Provinsi Bengkulu untuk tahun 2017 sampai 2019 dapat dilihat pada tabel 4 sebagai berikut :

\section{Tabel 4}

Data Kas dan Hutang Lancar tahun 2017 sampai 2019 (Dalam Rupiah)

\begin{tabular}{|c|c|c|}
\hline Tahun & Kas & Hutang Lancar \\
\hline 2017 & 164.456 .594 & 80.530 .174 \\
\hline 2018 & 456.116 .286 & 105.934 .830 \\
\hline 2019 & 489.730 .398 & 136.626 .124 \\
\hline
\end{tabular}

Sumber : Data diolah tahun 2020

Berdasarkan tabel 4 di atas struktur kas dan hutang lancar selama tahun 2017, 2018 dan 2019, maka besarnya cash ratio dapat dihitung sebagai berikut :

$$
\begin{aligned}
& \text { Cash Ratio } 2017=\frac{164.456 .594}{80.530 .174} \times 100 \% \\
& \text { Cash Ratio } 2018=\frac{456.116 .286}{105.934 .830} \times 100 \%
\end{aligned}
$$

$=430,56 \%$

Cash Ratio $2019=\frac{489.730 .398}{136.626 .124} \times 100 \%$

$=358,45 \%$

Dari hasil perhitungan tersebut maka besarnya cash ratio untuk tahun 2017 sampai dengan 2019 dapat dilihat pada tabel 5 berikut ini: 
Tabel 5

Cash Ratio

\begin{tabular}{|c|c|c|c|}
\hline Tahun & Ratio & Standar & $\begin{array}{c}\text { Keteranga } \\
n\end{array}$ \\
\hline 2017 & $\begin{array}{c}204,2 \\
2\end{array}$ & $\begin{array}{c}200 \% \text { s/d } \\
250 \%\end{array}$ & $\begin{array}{c}\text { Sehat } \\
\text { Sekali }\end{array}$ \\
\hline 2018 & $\begin{array}{c}430,5 \\
6\end{array}$ & $\begin{array}{l}<125 \% \text { atau } \\
>325 \%\end{array}$ & $\begin{array}{l}\text { Tidak } \\
\text { Sehat }\end{array}$ \\
\hline 2019 & $\begin{array}{c}358,4 \\
5\end{array}$ & $\begin{array}{l}<125 \% \text { atau } \\
>325 \%\end{array}$ & $\begin{array}{l}\text { Tidak } \\
\text { Sehat }\end{array}$ \\
\hline
\end{tabular}

Sumber: Hasil Pengolahan Data, 2020

Berdasarkan hasil perhitungan untuk cash ratio pada Koperasi Pegawai Negeri (KPN) Pemda Provinsi Bengkulu dari tahun 2017 sampai dengan tahun 2019 dapat dilihat bahwa kemampuan kas Koperasi Pegawai Negeri (KPN) Pemda Provinsi Bengkulu dalam melunasi hutang jangka pendeknya yaitu pada tahun 2017 sebesar 204,22 \% dengan penilaian sehat sekali, sedangkan tahun 2018 sebesar 430,56 \% dengan penilaian tidak sehat, tahun 2019 sebesar 358,45\% dengan penilaian tidak sehat. Hal ini mengambarkan bahwa kas yang ada pada Koperasi Pegawai Negeri (KPN Pemda Provinsi Bengkulu dapat menutupi semua hutang lancarnya. Namun penilaian cash ratio pada tahun 2018 dan 2019 dinilai tidak sehat, hal ini disebabkan karena banyaknya dana yang menggangur dalam bentuk kas dapat mengurangi kemampuan koperasi dalam mendapatkan laba atau keuntungan. Sebaiknya kas yang ada dapat disalurkan kepada anggota dalam bentuk pinjaman usaha.

\section{Aspek Tata Laksana dan Manajemen}

Aspek tata laksana dan manajemen merupakan rencana Anggaran dapat menjadi alat pengendalian manajemen perusahaan. Pengendalian tersebut meliputi kegiatan untuk membandingkan hasil aktual 3 (realisasi) dengan rencana yang dianggarkan serta mengambil tindakan koreksi atau umpan balik, sehingga apabila terjadi perbedaan antara realisasi dengan yang dianggarkan dapat diketahui perbedaan tersebut masih dalam batas-batas pengendalian manajemen maka harus dicari penyebab-penyebabnya agar dapat diambil tindakan korektif untuk menyeimbangkan antara rencana dan realisasi anggaran.

Realisasi Anggaran Pendapatan Koperasi $=\frac{\text { Realisasi }}{\text { Rencana }}$ X 100\%

Berdasarkan laporan keuangan pada Koperasi Pegawai Negeri (KPN) Pemda Provinsi Bengkulu pada lampiran 1, 2, 3 dan 4, maka dapat diketahui struktur Realisasi anggaran pendapatan koperasi untuk tahun 2017 sampai 2019 dapat disajikan pada tabel 9 sebagai berikut : 


\section{Tabel 6}

Data realisasi anggaran pendapatan koperasi tahun 2017 sampai 2019 (Dalam Rupiah)

\begin{tabular}{|c|c|c|}
\hline Tahun & Rencana & Realisasi \\
\hline 2017 & $328,420,000.00$ & $194,673,117.00$ \\
\hline 2018 & $6,262,745,877.00$ & $7,121,249,278.00$ \\
\hline 2019 & $413,517,432.00$ & $295,286,000.00$ \\
\hline
\end{tabular}

Sumber: Data diolah tahun 2020

Berdasarkan tabel di atas rencana dan realisasi anggaran selama tahun 2017, 2018 dan 2019, maka besarnya realisasi anggaran pendapatan koperasi dapat dihitung sebagai berikut :

$$
\begin{aligned}
& \text { RAP Tahun } 2017=\frac{194.673 .117,00}{328,420,000.00} \times 100 \% \\
& =60.27 \% \\
& \text { RAP Tahun } 2018=\frac{7 \cdot 121 \cdot 249.278,00}{6 \cdot 262.745 .877,00} \times 100 \% \\
& =113.7 \% \\
& \text { RAP Tahun } 2019=\frac{295.286 .000,00}{413.517 .432,00} \times 100 \% \\
& =71,4 \%
\end{aligned}
$$

Tabel 7

Hasil perhitungan realisasi anggaran pendapatan koperasi

\begin{tabular}{|l|l|l|l|}
\hline Tahun & \multicolumn{1}{|c|}{ Standar } & \multicolumn{1}{|c|}{ Nilai } & Kriteria \\
\hline 2017 & $60 \% \mathrm{~s} / \mathrm{d}<80 \%$ & $60.27 \%$ & Cukup Sehat \\
\hline 2018 & $>100 \%$ & $113.7 \%$ & Sehat sekali \\
\hline 2019 & $60 \% \mathrm{~s} / \mathrm{d}<80 \%$ & $71,4 \%$ & Cukup Sehat \\
\hline
\end{tabular}

Sumber: Data diolah tahun 2020

Pada tahun 2017 anggaran cenderung lebih besar dari realisasi yaitu rencana anggaran Rp. 328,420,000.00 dan realisasi Rp. 194,673,117.00 disini terdapat perbedaan Rp. 133.746.883,- dan anggaran cenderung lebih besar. Hal ini di sebabkan oleh terlalu besarnya rencana anggaran dibandingkan dengan biaya yang dikeluarkannya dan ada juga biaya yang sudah dianggarkan tetapi tidak ada realisasinya seperti dianggarkannya iuran wajib ke puskopad, biaya dik pengurus, dan bantuan ketua.

Pada tahun 2018 realisasi lebih besar dari rencana anggaran yaitu rencana anggaran Rp. 6,262,745,877.00 dan realisasi Rp. 7,121,249,278.00 terdapat selisih Rp. 858503401 hal ini disebabkan realisasi lebih besar di bandingkan dengan rencana anggaran, dan adanya biaya yang dikeluarkan tanpa direncanakan yaitu biaya ongkos umum, biaya administrasi bank, dan biaya inventaris.

Pada tahun 2019 keadaannya cenderung kembali pada tahun 2017 dimana rencana anggaran lebih besar dibandingkan dengan realisasi. Pada tahun 2019 ini anggarannya Rp. 413,517,432.00 sedangkan realisasinya Rp. 295,286,000.00 disini terdapat selisih Rp. 118.231.432,00. Hal ini disebabkan adanya biaya yang direncanakan tapi tidak ada realisasinya seperti adanya anggaran 
biaya iuran wajib puskop, biaya dik pengurus dan anggota, dan santunan dana kematian tetapi tidak ada realisasinya, dan juga terdapat banyak selisih biaya yang dianggarkan lebih besar dibandingkan dengan realisasinya.

Realisasi Anggaran Belanja Koperasi $=\frac{\text { Realisasi }}{\text { Rencana }}$ X 100\%

Berdasarkan laporan keuangan pada Koperasi Pegawai Negeri (KPN) Pemda Provinsi Bengkulu pada lampiran 1, 2, 3 dan 4, maka dapat diketahui struktur Realisasi anggaran belanja koperasi untuk tahun 2017 sampai 2019 dapat disajikan pada tabel 8 sebagai berikut :

Tabel 8

Data realisasi anggaran belanja koperasi tahun 2017 sampai 2019 (Dalam Rupiah)

\begin{tabular}{|c|c|c|}
\hline Tahun & Rencana & Realisasi \\
\hline 2017 & $3.001,345,000.00$ & $2.771,351,455.00$ \\
\hline 2018 & $5,518,023,041.00$ & $6,803,433,181.00$ \\
\hline 2019 & $2.750,874,873.00$ & $3.446,461,375.00$ \\
Sumber: Data diolah tahun 2020 \\
\hline
\end{tabular}

Berdasarkan tabel di atas rencana dan realisasi anggaran selama tahun 2017, 2018 dan 2019, maka besarnya realisasi anggaran belanja koperasi dapat dihitung sebagai berikut :

RAB Tahun $2017=\frac{2.771,351,455.00}{3.001,345,000.00} \times 100 \%$

$$
=92,33 \%
$$

RAB Tahun $2018=\frac{6,803,433,181.00}{5,518,023,041.00} \times 100 \%$

$$
=123.3 \%
$$

RAB Tahun $2019=\frac{3.446,461,375.00}{2.750,874,873.00} \times 100 \%$

$$
=125.2 \%
$$

Tabel 9

Hasil perhitungan realisasi anggaran belanja koperasi

\begin{tabular}{|c|l|c|l|}
\hline Tahun & Standar & Nilai & Kriteria \\
\hline 2017 & $<100 \%$ & $92.33 \%$ & $\begin{array}{l}\text { Sehat } \\
\text { sekali }\end{array}$ \\
\hline 2018 & $\begin{array}{l}>120 \% \text { s/d } \\
130 \%\end{array}$ & $123.3 \%$ & $\begin{array}{l}\text { Kurang } \\
\text { sehat }\end{array}$ \\
\hline 2019 & $\begin{array}{l}>120 \% \text { s/d } \\
130 \%\end{array}$ & $125.2 \%$ & $\begin{array}{l}\text { Kurang } \\
\text { sehat }\end{array}$ \\
\hline
\end{tabular}

Sumber: Data diolah tahun 2020

Pada tahun 2017 anggaran cenderung lebih besar dari realisasi yaitu rencana anggaran Rp. 3.001,345,000.00 dan realisasi Rp. 2.771,351,455.00 disini terdapat perbedaan Rp. 229.993.545,dan anggaran cenderung lebih besar. Hal ini di sebabkan oleh terlalu besarnya rencana anggaran 
dibandingkan dengan biaya yang dikeluarkannya dan ada juga biaya yang sudah dianggarkan terlalu besar dari realisasi yang ada. Pada tahun 2017 diangap menguntungkan koperasi, hal ini menunjukkan bahwa anggaran yang disusun berfungsi secara efektif. Pada tahun 2018 dan 2019 menunjukkan bahwa realisasi biaya yang tinggi dari anggaran yang dibuat, persentase mencapai 123,3\% pada tahun 2018 dan 125,2\% pada tahun 2019, hal ini disebabkan karena adanya biayabiaya yang tak terduga atau meningkat yang tidak sesuai dengan rencana misalnya meningkatnya biaya RAT dan meningkatnya pengeluaran untuk membayar pajak.

\section{Aspek Produktivitas}

Aspek Produktivitas merupakan rasio yang digunakan untuk menggambarkan kemampuan Koperasi Pegawai Negeri (KPN) Pemda Provinsi Bengkulu dalam mencari keuntungan atau sisa hasil usaha dari tahun 2017 sampai tahun 2019. Rasio yang digunakan dalam analisis rentabilias adalah :

1. Rentabilitas Modal Sendiri

Rentabilitas modal sendiri merupakan rasio yang menunjukkan efisiensi penggunaan modal sendiri.

Rentabilitas Modal Sendiri $=\frac{\text { Sisa Hasil Usaha }}{\text { Modal Sendiri }} \times 100 \%$

Berdasarkan laporan keuangan Koperasi Pegawai Negeri (KPN) Pemda Provinsi Bengkulu seperti pada lampiran 1, 2, 3 dan 4, maka data diketahui struktur Sisa Hasil Usaha dan modal sendiri dapat dilihat pada tabel 10 berikut :

\section{Tabel 10}

Data Sisa Hasil Usaha dan Modal Sendiri tahun 2017 sampai 2019 (Dalam Rupiah)

\begin{tabular}{|c|c|c|c|}
\hline Tahun & Ratio & Standar & Keterangan \\
\hline 2017 & 18,90 & $15 \%$ s/d <21\% & Sehat \\
\hline 2018 & 18,55 & $15 \%$ s/d <21\% & Sehat \\
\hline 2019 & 18,13 & $15 \%$ s/d <21\% & Sehat \\
Sumber: Data diolah tahun 2020 & \\
\hline
\end{tabular}

Berdasarkan tabel di atas maka rentabilitas modal sendiri pada Koperasi Pegawai Negeri (KPN) Pemda Provinsi Bengkulu untuk tahun 2017 sampai 2019 dapat dihitung sebagai berikut :

Rentabilitas Modal Sendiri $2017=\frac{523.093 .117}{2.768 .251 .905} \times 100 \%$

$=18,90 \%$

Rentabilitas Modal Sendiri $2018=\frac{627.337 .681}{3.381 .030 .701} \times 100 \%$

$=18,55 \%$

Rentabilitas Modal Sendiri $2019=\frac{708.803 .432}{3.909 .300 .024} \times 100 \%$

$=18,13 \%$

Dari hasil perhitungan tersebut diketahui besarnya rentabilitas modal sendiri untuk tahun 2017 sampai dengan 2019 dapat seperti terlihat pada tabel 11 berikut ini : 


\section{Tabel 11}

Hasil Perhitungan Rentabilitas Modal Sendiri periode 2017-2019

\begin{tabular}{|c|c|c|}
\hline Tahun & Sisa Hasil Usaha & Asset \\
\hline 2017 & 523.093 .117 & 4.681 .700 .772 \\
\hline 2018 & 627.337 .681 & 4.145 .092 .209 \\
\hline 2019 & 708.803 .432 & 4.045 .926 .148 \\
Sumber: Hasil Pengolahan Data, 2020 \\
\hline
\end{tabular}

Berdasarkan hasil perhitungan untuk rentabilitas modal sendiri pada Koperasi Pegawai Negeri (KPN) Pemda Provinsi Bengkulu dari tahun 2017 sampai dengan tahun 2019 dapat dilihat bahwa kemampuan Koperasi Pegawai Negeri (KPN) Pemda Provinsi Bengkulu dalam mendapatkan keuntungan atau sisa hasil usaha dilihat dari nilai modal sendiri (equity) dapat diketahui bahwa pada tahun 2017 nilai rentabilias modal sendiri sebesar 18,90 \% dengan penilaian sehat, tahun 2018 sebesar 18,55 \% dengan penilaian sehat, tahun 2019 sebesar 18,13\% dengan penilaian sehat karena angka-angka tersebut berada diantara 15\% - 21\%. Hal ini menggambarkan bahwa penilain terhadap rasio rentabilitas modal sendiri pada Koperasi Pegawai Negeri (KPN) Pemda Provinsi Bengkulu diketahui sehat, karena koperasi mampu mengelola modalnya dengan baik karena koperasi tidak mengalami rugi dan koperasi dapat mencapai keuntungan yang selalu meningkat dari tahun ketahun. Namun jika dilihat dari penilaian rasio rentabilitas terjadi penurunan dari tahun 2017 sampai 2019 hal ini disebabkan karena kenaikan Sisa Hasil Usaha tidak seimbang dengan kenaikan modal sendiri.

\section{Return On Asset (ROA)}

Return on asset merupakan merupakan perbandingan antara hasil usaha yang diperoleh dengan asset koperasi pada tahun yang bersangkutan pada Koperasi Pegawai Negeri (KPN) Pemda Provinsi Bengkulu. Adapun rumus yang digunakan untuk menghitung Return On Asset (ROA) adalah :

$$
\text { ROA }=\frac{\text { Sisa Hasil Usaha }}{\text { Asset }} \times 100 \%
$$

Berdasarkan laporan keungan pada Koperasi Pegawai Negeri (KPN) Pemda Provinsi Bengkulu pada lampiran 1, 2, 3 dan 4, maka dapat diketahui struktur Sisa Hasil Usaha dan Asset untuk tahun 2017 sampai 2019 dapat disajikan pada tabel 12 sebagai berikut :

\section{Tabel 12}

Data Sisa Hasil Usaha dan Asset tahun 2017 sampai 2019 (Dalam Rupiah)

\begin{tabular}{|c|c|c|}
\hline Tahun & $\begin{array}{c}\text { Sisa Hasil } \\
\text { Usaha }\end{array}$ & Modal Sendiri \\
\hline 2017 & 523.093 .117 & 2.768 .251 .905 \\
\hline 2018 & 627.337 .681 & 3.381 .030 .701 \\
\hline 2019 & 708.803 .432 & 3.909 .300 .024 \\
Sumber: & Data diolah tahun 2020 \\
\hline
\end{tabular}

Dari hasil perhitungan tersebut di atas maka besarnya return on asset untuk tahun 2017 sampai dengan tahun 2019 dapat dihitung sebagai berikut:

Return On Asset $2017=\frac{523.093 .117}{4.681 .700 .772} \times 100 \%$ 
$=11,17 \%$

Return On Asset $2018=\frac{627.337 .681}{4.145 .092 .209} \times 100 \%$

$=15,13 \%$

Return On Asset $2019=\frac{708.803 .432}{4.045 .926 .148} \times 100 \%$

$=17,52 \%$

Dari hasil perhitungan tersebut di atas maka besarnya return on asset untuk tahun 2017 sampai dengan 2019 dapat dilihat pada tabel 13 berikut ini :

\begin{tabular}{|c|c|c|c|}
\hline Tahun & Ratio & Standar & Keterangan \\
\hline 2017 & 11,17 & $\geq 10 \%$ & $\begin{array}{c}\text { Sehat } \\
\text { Sekali }\end{array}$ \\
\hline 2018 & 15,13 & $\geq 10 \%$ & $\begin{array}{c}\text { Sehat } \\
\text { Sekali }\end{array}$ \\
\hline 2019 & 17,52 & $\geq 10 \%$ & $\begin{array}{c}\text { Sehat } \\
\text { Sekali }\end{array}$ \\
\hline
\end{tabular}

Sumber: Hasil Pengolahan Data, 2020

Berdasarkan hasil perhitungan untuk ratio return on asset (ROA) pada Koperasi Pegawai Negeri (KPN) Pemda Provinsi Bengkulu dari tahun 2017 sampai dengan tahun 2019 dapat diketahui bahwa kemampuan Koperasi Pegawai Negeri (KPN) Pemda Provinsi Bengkulu dalam mendapatkan keuntungan atau sisa hasil usaha dilihat dari nilai aktiva pada tahun 2017 nilai ratio rentabilitas ekonomi sebesar 11,17 \% dengan penilaian sehat sekali, tahun 2018 sebesar 15,13\% dengan penilaian sehat sekali, tahun 2019 sebesar 17,52\% dengan penilaian sehat sekali karena angka tersebut besar dari 10\%. Hal ini menggambarkan bahwa penilain rasio rentabilitas yang dinilai dari ratio return on asset pada Koperasi Pegawai Negeri (KPN) Pemda Provinsi Bengkulu sehat sekali, karena koperasi mampu mengeefektifkan perusahaannya dalam mengelola asset koperasi sehingga koperasi dapat meningkatkan laba atau sisa hasil usaha dari tahun 2017 sampai tahun 2019.

Berdasarkan penilaian terhadap rasio likuiditas dan rentabilitas yang telah peneliti lakukan di Koperasi Pegawai Negeri (KPN) Pemda Provinsi Bengkulu, maka analisis rasio likuiditas dan rentabilias pada Koperasi Pegawai Negeri (KPN) Pemda Provinsi Bengkulu dari tahun 2017 sampai dengan 2019 dapat dilihat pada tabel 14 berikut ini :

Tabel 14

Rekapitulasi Ratio Likuiditas dan Rentabilitas pada Koperasi Pegawai Negeri (KPN) Pemda Provinsi Bengkulu tahun 2017 sampai dengan 2019.

\begin{tabular}{|l|c|c|c|}
\hline Rasio keuangan & Tahun & Nilai & Predikat \\
\hline Current Rasio & 2017 & $5.434,93$ & Tidak Sehat \\
\hline & 2018 & $3.655,88$ & Tidak Sehat \\
\hline Cash Rasio & 2019 & $2.748,35$ & Tidak Sehat \\
\hline & 2017 & 204,22 & Sehat Sekali \\
\hline
\end{tabular}




\begin{tabular}{|l|c|c|c|} 
& 2019 & 358,45 & Tidak Sehat \\
\hline Realisasi anggaran pendapatan & 2017 & $60.27 \%$ & Cukup Sehat \\
\hline & 2018 & $113.7 \%$ & Sehat sekali \\
\hline Realisasi anggaran belanja & 2019 & $71,4 \%$ & Cukup Sehat \\
\hline & 2017 & $92.33 \%$ & Sehat sekali \\
\hline & 2018 & $123.3 \%$ & Kurang sehat \\
\hline Rentabilitas Modal Sendiri & 2019 & $125.2 \%$ & Kurang sehat \\
\hline & 2017 & 18,90 & Sehat \\
\hline & 2018 & 18,55 & Sehat \\
\hline Return on Asset & 2019 & 18,13 & Sehat \\
\hline & 2017 & 11,17 & Sehat Sekali \\
\hline & 2018 & 15,13 & Sehat Sekali \\
\hline
\end{tabular}

Sumber: Hasil Pengolahan Data, 2020

Berdasarkan hasil penelitian rasio likuiditas koperasi dalam kategori tidak baik. Menurut Munawir (2013:49) hal ini mengindikasikan bahwa Koperasi Pegawai Negeri (KPN) Pemda Provinsi Bengkulu menunjukan adanya kelebihan aktiva lancar, sehingga akan berpengaruh tidak baik bagi profitabilitas koperasi. Selain itu juga mengindikasikan adanya kelebihan uang kas atau aktiva lancar lainnya dibandingkan dengan yang dibutuhkan sekarang atau tingkat tingkat likuiditas yang rendah dari pada aktiva lancar. Koperasi Pegawai Negeri (KPN) Pemda Provinsi Bengkulu memiliki jumlah aktiva lancar yang besar dan memiliki hutang lancar yang kecil, sehingga berpengaruh buruk pada profitabilitas perusahaan yaitu kemungkinan tidak tertagihnya piutang sangat besar.

Hasil perhitungan realisasi anggaran pendapatan pada Koperasi Pegawai Negeri (KPN) Pemda Provinsi Bengkulu dari tahun 2017 dan tahun 2019 yaitu memiliki penilaian yang cukup sehat Hal ini di sebabkan oleh besarnya rencana anggaran dibandingkan dengan biaya yang dikeluarkannya seperti pada biaya RAT yang dianggarkan lebih besar daripada realisasinya. Hal ini disebabkan telah memiliki perencanaan yang matang dan terencana dengan baik pada Koperasi Pegawai Negeri (KPN) Pemda Provinsi Bengkulu dan proses realisasinya sesuai dengan rencana, Namun pada tahun 2018 memiliki penilaian yang sehat sekali hal ini dikarenakan adanya biaya yang dikeluarkan dengan perencanaan yang tepat sasaran sesuai dengan perencanaan awal yaitu biaya ongkos umum, biaya adm bank, dan biaya inventaris sudah mauk ke dalam perencanaan. Rasio rentabilitas merupakan kemampuan Koperasi Pegawai Negeri (KPN) Pemda Provinsi Bengkulu dalam mencari keuntungan dari tahun 2017 sampai tahun 2019, dilihat dari rentabilitas modal sendiri dan return on asset. Hasil perhitungan untuk rentabilitas modal sendiri pada Koperasi Pegawai Negeri (KPN) Pemda Provinsi Bengkulu dari tahun 2017 sampai dengan tahun 2019 yaitu pada tahun 2017 nilai rentabilias modal sendiri mendapatkan kriteria penilaian sehat.

Hasil perhitungan untuk ratio return on asset pada Koperasi Pegawai Negeri (KPN) Pemda Provinsi Bengkulu dari tahun 2017 sampai dengan tahun 2019 yaitu memiliki penilaian yang sangat sehat. Hal ini menggambarkan bahwa penilain kinerja keuangan Koperasi Pegawai Negeri (KPN) Pemda Provinsi Bengkulu dari return on asset sudah sehat sekali, karena koperasi mampu 
mengeefektifkan perusahaannya dalam mengelola asset koperasi dengan baik sehingga koperasi dapat meningkatkan laba atau sisa hasil usaha dari tahun ke tahun.

Return On Asset (ROA) merupakan perbandingan dari sisa hasil usahadengan aset yang dimiliki oleh koperasi. Berdasarkan hasil penelitian menunjukan koperasi mempunyai nilai return on asset yang sehat sekali. Menurut Riyanto (2010:36) hal tersebut menunjukan adanya kesesuaian antara aset dengan hasil usaha yang diperoleh oleh koperasi. Dilihat dari rata-rata maka ROA sudah sesuai dengan ketentuan yang berlaku yaitu ROA dikatakan baik karena berada standar yang digunakan. Tingkat ROA mencerminkan kemampuan aset dalam menghasilkan laba, dengan demikian tingkat ROA yang tinggi merupakan pencerminan efisiensi yang tinggi pula. Koperasi dapat meningkatkan mengoptimalkan pendapatan dengan meminimalkan biaya usaha sehingga SHU yang diperoleh akan meningkat.

\section{KESIMPULAN DAN SARAN}

\section{Kesimpulan}

Berdasarkan hasil penelitian analisis kinerja keuangan yang telah dilakukan di Koperasi Pegawai Negeri (KPN) Pemda Provinsi Bengkulu dapat diambil kesimpulan bahwa:

a. Hasil analisis likuiditas dilihat dari current ratio dan cash ratio. Current ratio tahun 2017 sebesar 5.434,93 \% dengan penilaian tidak sehat, tahun 2018 sebesar 3.655,88 \% dengan penilaian tidak sehat, tahun 2019 sebesar 2.748,35 \% dengan penilaian tidak sehat. Hal ini mengambarkan bahwa aktiva lancar Koperasi Pegawai Negeri (KPN) Pemda Provinsi Bengkulu dapat menutupi semua hutang lancarnya.

b. Hasil Analisis Aspek Tata Laksana dan Manajemen dari rasio realisasi anggaran pendapatan koperasi pada tahun 2017 dan 2019 cukup sehat yaitu masing-masing $60.27 \%$ dan 71,4\% hal ini menggambarkan bahwa realisasi anggaran sudah sepenuhnya sesuai dengan rencana anggaran, namun terdapat beberapa yang sudah dianggarkan namun tidak berjalan, sedangkan rasio anggaran pendapatan koperasi pada tahun 2018 sehat sekali pada Koperasi Pegawai Negeri (KPN) Pemda Provinsi Bengkulu karena rencana anggaran pendapatan koperasi yang sudah dianggarkan dapat direalisasikan dengan baik dan tepat, dan terdapat anggaran yang sudah direalisasikan namun belum termasuk ke dalam perencanaan.

c. Hasil analisis rentabilitas dilihat dari rasio rentabilitas modal sendiri dan ratio return on asset (ROA). Rentabilitas modal sendiri pada tahun 2017 sebesar 18,90 \% dengan penilaian sehat, tahun 2018 sebesar 18,55 \% dengan penilaian sehat, tahun 2019 sebesar 18,13\% dengan penilaian sehat karena angka-angka tersebut berada diantara $15 \%$ - $21 \%$. Hal ini menggambarkan bahwa penilain terhadap rasio rentabilitas modal sendiri pada Koperasi Pegawai Negeri (KPN) Pemda Provinsi Bengkulu diketahui sehat, karena koperasi mampu mengelola modalnya dengan baik karena koperasi tidak mengalami rugi dan koperasi dapat mencapai keuntungan yang selalu meningkat dari tahun ketahun.

\section{Saran}

Berdasarkan kesimpulan maka penulis memberikan saran sebagai berikut:

a. Diharapkan kepada Koperasi Pegawai Negeri (KPN) Pemda Provinsi Bengkulu untuk dapat memanfaatkan semua harga dan kas yang tersedia sebaik mungkin sehingga koperasi mampu mendapatkan laba yang lebih maksimal. 
b. Dalam proses perencanaan anggaran Koperasi Pegawai Negeri (KPN) Pemda Provinsi Bengkulu sebaiknya memiliki perencanaan yang tepat sehingga anggaran dapat direalisasikan dengan tepat.

c. Sebaiknya Koperasi Pegawai Negeri (KPN) Pemda Provinsi Bengkulu senantiasa lebih meningkatkan lagi usahanya dengan menambah jenis usaha lainnya untuk dapat meningkatkan laba koperasi.

\section{DAFTAR PUSTAKA}

Afriyanti. 2011, Analisa Laporan Keuangan, Alfabeta, Bandung.

Amstrong, 2014, Modal Organisasi. PT. Raja Grafindo Persada, Jakarta.

Hadi, 2011, Manajemen Perusahaan Koperasi, Erlangga :Jakarta.

Harahap, 2015, Analisis Kritis Atas Laporan Keuangan. Cetakan. Kesepuluh. Jakarta: PT RajaGrafindo Persada

Harmono, 2012, Manajemen Keuangan Berbasis Balanced Scorecard (Pendekatan Teori, Kasus, dan Riset Bisnis), Bumi Aksara, Jakarta.

Kartasapoetra. G. dkk. 2010. Koperasi Indonesia. Rineka Cipta : Jakarta

Kasmir, 2011, Pengantar Manajemen Keuangan, Edisi Kedua, Cetakan ke-4, Jakarta:

Prenadamedia group

Martono dan Agus Harjito, 2013, Manejemen Keuangan, edisi pertama, cetakan pertama, Penerbit : Ekonisia Kampus Fakultas Ekonomi UII, Yogyakarta

Munawir, 2010, Analisa Laporan Keuangan, edisi pertama, cetakan keempatbelas, BPFE, Yogyakarta

Peraturan Menteri Negara Koperasi dan UKM Republik Indonesia Nomor 06/Per/M.KUKM/V/2006 tanggal 1 Mei 2006 tentang Pedoman Penilaian Koperasi Berprestasi/Koperasi Award

Peraturan Menteri Negara Koperasi dan UKM Republik Indonesia Nomor 14/Per/M.KUKM/XII/2009 tanggal 22 Desember 2009 tentang Pedoman Penilaian Kesehatan Koperasi Simpan Pinjam dan Unit Simpan Pinjam Koperasi

Riyanto.. 2010. Manajemen Keuangan dan Akutansi Untuk Eksekutif Per 'T. Raja Grafindo Persada, Jakarta.

Rudianto. 2012. Pengantar Akuntansi Konsep dan Teknik Penyusunan Laporan Keuangan. Erlangga, Jakarta.

Sugiyono. 2013. Metode Penelitian Kuantitatif Kualitatif dan R\&D. Alfabeta. Bandung.

Sumitro, 2010. Persamaan Koperasi dengan Gotong Royong. Lembaga Penerbitan UNM, Makassar. Susni, Susmita, 2012, Analisis Modal Kerja Terhadap Rentabilitas Pada Koperasi Pemerintah Daerah (PEMDA) Provinsi Bengkulu, Universitas Dehasen Bengkulu

Sutrisno, 2012, Manajemen Keuangan, Teori, Konsep dan Aplikasi, edisi pertama, cetakan ketiga, Penerbit : Ekonesia, Yogyakarta.

Undang-Undang Republik Indonesia No. 25 Tahun 1992 Tentang Perkoperasian.

Wahyudin. 2011. Pembelajaran dan Model-model Pembelajaran. Jakarta: CV. Ipa Abong

Widiyanti, Ninim dan Sunindhia, Y.W. 2011. Koperasi dan Perekonomian Indonesia Jakarta : Rineka Cipta. 